\title{
ROBERTA SEELINGER TRITES \\ LITERARY CONCEPTUALIZATIONS OF GROWTH
}

\author{
Amsterdam, Philadelphia: John Benjamins Publishing Company, \\ 2014 (164 s.)
}

Roberta Seelinger Trites har haft ett stort inflytande på den nordiska barnlitteraturforskningen. Både Waking Sleeping Beauty (1997), om den feministiska barnromanen, och Disturbing the Universe (2000), om maktstrukturer och de institutioner som formar ungdomsromanen, har vitaliserat forskningen. Hennes senaste bok, Literary Conceptualizations of Growth, tar ett helhetsgrepp på mötet mellan hjärnforskning och litteraturanalys. Detta görs genom att granska hur växande begreppsliggörs i filosofi, ungdomsromaner och barnlitteraturforskning. Främst granskar Trites växande som metafor. Boken är trots sin höga ambitionsnivå och de teoretiska resonemang som frågeställningen för med sig flyhänt skriven och lättillgänglig.

Vad bidrar då den hypade hjärnforskningen med på barn- och ungdomsboksfältet? I många fall tycks kognitiv teori klistras på som en obligatorisk svans på åsnan, mer sällan riktigt placerad. I Trites fall är det tvärtom. Hon är föredömligt pedagogisk då hon visar att kognitiv narratologi kan avtäcka djupliggande strukturer i berättandet för unga. Hon stöder sig på Lakoff och Johnsons studie om metaforer vi lever genom och visar hur berättarstrukturer genomsyras av eller harmonierar med kognitiva strukturer. De nyckelbegrepp hon arbetar med är sekvens, skript och schema, termer som bland andra John Stephens laborerat med tidigare. Trites menar att förståelse alltid är förkroppsligad och att språket utgör den bro som gör förståelse möjlig. Hon fokuserar genomgående på samspelet mellan kognition och förkroppsligad erfarenhet av växande. I analyserna konkretiserar hon sedan hur vi begreppsliggör växande i film och litteratur. En hel del av våra förhandsuppfattningar handlar nämligen om att vi tolkar enligt färdiga skript. Ett skript är exempelvis "manlig omognad", något som betraktas som normaliserat.

(C)2015 Mia Österlund. This is an Open Access article distributed under the terms of the Creative Commons Attribution-Noncommercial 3.0 Unported License (http://creativecommons.org/ licenses/by-nc/3.0/), permitting all non-commercial use, distribution, and reproduction in any medium, provided the original work is properly cited.

Citation: Barnboken - tidskrift för barnlitteraturforskning/Barnboken - Journal of Children's Literature Research, Vol. 38, 2015 http://dx.doi org/10.14811/clr.v38io.209 
Sekvenser, skript och stereotypt vetande är samtliga biopsykiskt och kulturellt situerade. Det kan handla om skriptet tretal, som realiseras i Guldlock och de tre björnarna. Men litterära texter kan också bjuda på kognitiva dissonanser där normer och stereotyper bryts ner. Trites bakar också in mer personliga ställningstaganden och motiverar bland annat varför hon slutat läsa Laurie Halse Andersons våldtäktsskildring Speak med sina studenter, som blev för illa berörda av romanen. Hon är också klar över att alla romaner inte passar hennes resonemang. Det finns inga "en storlek passar alla"-lösningar, konstaterar hon. Genom begreppet blending, förening, lyfter Trites vidare fram kulturens inflytande på hjärnan som ett sätt att förändra dominerande berättelsemönster. Hennes exempel ur ungdomslitteraturen må vara angloamerikanska, men är intressanta och ofta välkända för en nordisk läsekrets. Exempelvis diskuterar hon David Almonds Mitt namn är Mina och Skellig samt Sherman Alexies The Absolutely True Diary of a Part-Time Indian.

Trites metaläsning av barnlitterära studier av Seth Lerer, Karin Lesnik-Oberstein, Beverly Lyon Clark och Kim Reynolds är särskilt givande. Metoden är historiografisk och utgår från foucaultiansk arkeologi som blottlägger hur växandet fungerar som en metadiskurs i forskningen. Hur privilegierar forskningen växandet som perspektiv och varför är det så dominerande? En viktig fråga Trites ställer är om forskningen klamrar sig fast vid växandemetaforiken på bekostnad av andra begreppsliggöranden.

Trites lyfter själv fram frågan om hur hon som feminist ska förhålla sig till kognitiva strukturer och till kulturens tendens att kopiera sina grundläggande idéer och därmed konservera maktstrukturer. Det hon gör påminner de facto om Butlers heterosexuella matris, men i Trites tappning formeras en växandets matris. Att ungdomsromaner kan upphöra med sin fixering vid att förhålla sig till växande och mognad och istället beskriva varande och misslyckat mognande vet vi, och det gör diskussionen om växande än mer spännande.

Mia Österlund

Docent i litteraturvetenskap

Åbo Akademi 